\title{
The Contribution of Luteinizing Hormone to Alzheimer Disease Pathogenesis
}

\author{
Kate M. Webber, PhD; George Perry, PhD; \\ Mark A. Smith, PhD; and Gemma Casadesus, PhD
}

\begin{abstract}
Several hypotheses have been proposed that attempt to explain the pathogenesis of Alzheimer Disease (AD) including theories involving senile plaque and neurofibrillary tangle formation, increased oxidative stress, and cell cycle abnormalities, since evidence for each of these pathological phenomena have been well documented in AD. Recent epidemiological and experimental data also support a role for the gonadotropin luteinizing hormone in $A D$. Paralleling the female predominance for developing $A D$, luteinizing hormone levels are significantly higher in females as compared to males, and furthermore, luteinizing hormone levels are higher still in individuals who succumb to $A D$. Luteinizing hormone, which is capable of modulating cognitive behavior, is not only present in the brain, but also has the highest receptor levels in the hippocampus, a key processor of cognition that is severely deteriorated in AD. Furthermore, we recently examined cognitive performance in a well-characterized transgenic mouse that over-expresses luteinizing hormone and found that these animals show decreased cognitive performance when compared to controls. We have also found that abolishing luteinizing hormone in amyloid- $\beta$ protein precursor transgenic mice (Tg2576) using a potent gonadotropin-lowering gonadotropin-releasing hormone agonist, leuprolide acetate, resulted in improved hippocampally-related cognitive performance and decreased amyloid- $\beta$ deposition. These findings, together with data indicating that luteinizing hormone modulates amyloid- $\beta$ protein precursor processing in vivo and in vitro, suggest that luteinizing hormone may contribute to $A D$ pathology through an amyloid-dependent mechanism. These promising findings support the importance of luteinizing hormone in $A D$ and bring to the forefront an alternative, and much needed, therapeutic avenue for the treatment of this insidious disease.
\end{abstract}

Key words: Alzheimer Disease; Amyloid- $\beta$; Cognition; Luteinizing hormone

\begin{abstract}
A
lzheimer Disease (AD) is the most prevalent neurodegenerative disease affecting more than 15 million people worldwide ${ }^{1}$ and is characterized by selective neuronal degeneration resulting in progressive memory loss. ${ }^{2} \mathrm{AD}$ attacks several different regions of the brain including the cerebral cortex which is involved in conscious thought and language, the basal forebrain which is important in memory and learning, and the hippocampus which is essential to memory storage. Clinical manifestations of AD are varied but can include memory loss, difficulty performing familiar tasks, disorientation to time and place, misplacing things, and changes in mood or behavior. ${ }^{3}$ Several hypotheses have been proposed in attempts to explain the pathogenesis of $\mathrm{AD}$
\end{abstract}

Reprint Requests: Mark A. Smith, PhD, Department of Pathology, Case Western Reserve University, 2103 Cornell Road, Cleveland, Ohio 44I06 USA, Tel: 2I6-368-3670, Fax: 2I6-368-8964, Email: mark.smith@case.edu

Received: December 19, 2006

Revised: May 10, 2007

Accepted: May 16, 2007 and include theories involving senile plaque and neurofibrillary tangle formation, increased oxidative stress, and cell cycle abnormalities, since evidence for each of these pathological phenomena have been well documented in $\mathrm{AD} .{ }^{4}$

The senile plaque, which is primarily composed of the 4.2 $\mathrm{kDa}$ amyloid- $\beta$ polypeptide, is produced from the proteolytic cleavage of the larger amyloid- $\beta$ precursor protein (A $\beta \mathrm{PP})$ and is the extracellular hallmark of AD. To date, three genes involving A $\mathrm{PP}$ or its cleavage product have been identified as containing fully penetrant, mutations resulting in early-onset AD. These mutations can be found on genes encoding A $\beta P$ P itself and also on presenilin-1 and presenilin-2 genes. ${ }^{5}$ While these mutations are known to

Grant Support: National Institutes of Health, Alzheimer's Association, and Philip Morris USA Inc and Philip Morris International. 
dramatically increase susceptibility to AD at early ages, only a small percentage of total AD cases can be attributed to these rare mutations, suggesting that there is another, non-mutation-based amyloid- $\beta$-dependent mechanism contributing to $\mathrm{AD}$ pathogenesis.

Neurofibrillary tangles comprise the major intracellular protein component in $\mathrm{AD}$ and are primarily composed from a hyper-phosphorylated form of the microtubule-associated protein called tau. 6,7 The high level of tau phosphorylation seen in AD is thought to cause a destabilization of neuronal microtubular dynamics which ultimately results in neuronal dysfunction. 8,9 While the kinases responsible for tau phosphorylation in $\mathrm{AD}$ are not completely characterized, hyperphosphorylation of tau also occurs in healthy, mitotically active neurons where phosphorylation is driven by cyclin-dependent kinases (CDK). ${ }^{10-14}$ Of note, CDKs such as CDK2 and CDK5, as well as cdc-kinases and mitogen-associated protein kinases, are increased in AD in a topographical manner that overlaps with hyperphosphorylated tau. ${ }^{15,16}$ In vitro assays have demonstrated these kinases also cause the hyperphosphorylation of tau. ${ }^{17-21}$ This suggests that tau hyperphosphorylation in $\mathrm{AD}$ may involve kinases also responsible for normal physiological tau phosphorylation.

While the presence of oxidative stress and free radical damage in AD pathogenesis has been well established, ${ }^{22-24}$ the mechanism behind free-radical generator/antioxidant disequilibrium in AD has yet to be elucidated.25-27 Similarly, although neuronal changes supporting the involvement of cell cycle abnormalities in the etiology of $\mathrm{AD}$, which include the ectopic expression of cell cycle markers, ${ }^{28}$ organelle kinesis 29 and cytoskeletal alterations ${ }^{27}$ are evident, the events leading to these pathogenic changes are unknown. Nevertheless, mounting evidence for the participation of both oxidative stress and cell cycle abnormalities in the etiology of AD suggests that both of these phenomena play a fundamental role in AD. ${ }^{30}$ Considering that senile plaques, neurofibrillary tangles, increased oxidative stress and cell cycle abnormalities all likely contribute to AD pathogenesis, it is clear that the events leading up to neuronal death and ultimately dementia in AD are not only highly complex, but also probably are integrated.

Due to the extended course of the disease, the etiologic events leading to the neuronal loss and dysfunction in $\mathrm{AD}$ are difficult to determine; however, recent evidence suggesting a gender-based predisposition towards AD in females that is not found in other dementias such as Parkinson's, supports a role for hormones in AD pathogenesis. Epidemiological studies exploring gender differences in AD have resulted in conflicting data, although most studies support the higher prevalence $^{31-34}$ and incidence 35 of AD in women. Since gender and age are two of the biggest risk factors for AD, it has been hypothesized that hormonal deficiency following reproductive senescence may contribute to the etiology of AD.
Interestingly, the long held notion of the pathogenic effects of decreased sex hormone levels, namely estrogen, on the brain after reproductive senescence is not consistently reflected in studies measuring sex hormone levels in $\mathrm{AD}$ compared to age-matched controls. For example, only one of nine recent observational studies comparing estrogen levels in women with $\mathrm{AD}$ to controls reported lower estrogen levels in $\mathrm{AD},{ }^{36}$ with three studies reporting increased estrogen levels in $\mathrm{AD}^{37-39}$ and five reporting no significant differences between AD and controls. ${ }^{40-44}$ The variability in the results of these studies is thought to be caused in part by the sensitivity of the assay used, as studies that used less sensitive assays reported higher total estrogen levels, ${ }^{39}$ and resulted in overestimation of the impact of low estrogen levels on the study. However, it is worth noting that the majority of these studies were conducted on samples of relatively elderly women who were many years postmenopause and whose current hormone levels do not necessarily reflect levels in premenopausal periods or in the immediate postmenopausal period that appears to be a critical window for the protective effect of estrogen or hormone replacement therapy. A few studies have examined the relationship of endogenous estrogen levels to cognitive decline in healthy women or to risk of AD, although the results have been inconsistent. Several studies have found an association between elevated sex-hormone binding globulin, or low bioavailable estradiol, and cognitive decline or $\mathrm{AD}$, and it is likely that biologically active or free estradiol, rather than total estradiol, may be the active agents in the central nervous system and may be more important in maintaining cognitive performance. ${ }^{45}$ Additionally, there is growing literature on the role of polymorphisms in the estrogen receptor activity on risk of AD. ${ }^{46,47}$ These effects are likely to be independent of hormone levels.

In addition to inconsistent data, studies reporting no improvement in cognitive function with estrogen plus progestin treatment ${ }^{48}$ cast serious doubt on the role of sex hormones in AD pathogenesis. Similarly, a decline in estrogen or testosterone does not explain why males with Down's syndrome are at significantly higher risk of developing AD-type changes and at an earlier age than their female counterparts. ${ }^{49}$ This shift in the normally gender-based predisposition of $\mathrm{AD}$ is not the result of decreased levels of estrogen or testosterone in patients with Down Syndrome because the levels of these hormones in Down Syndrome patients are comparable to the general population.

While most research evaluating how differences in gender contribute to $\mathrm{AD}$ pathogenesis is primarily focused on the sex hormones, estrogen and testosterone, there are a number of other hormones that regulate reproductive function in conjunction with sex hormones, forming the hypothalamic-pituitary-gonadal (HPG) axis. Like estrogen and testosterone, the other hormones of the HPG axis also undergo drastic changes in their level of expression induced by the onslaught of reproductive senescence. Among these 
hormones are gonadotropin-releasing hormone $(\mathrm{GnRH})$ and the gonadotropins, which are heterodimers consisting of a common $\alpha$-gonadotropin subunit and a gonadotropin-specific $\beta$ subunit that are non-covalently bound. The gonadotropin family includes luteinizing hormone (LH), human chorionic gonadotropin, follicle-stimulating hormone and thyroid-stimulating hormone; however, only LH and follicle-stimulating hormone are primarily involved in HPG axis regulation as thyroid-stimulating hormone regulates thyroid function, and human chorionic gonadotropin plays an essential role in pregnancy.

Interestingly, receptors for some of these gonadotropin hormones are expressed in many non-reproductive tissues including, most notably, the brain. ${ }^{50,51}$ When this is taken into consideration along with the incomplete protection of hormone replacement therapy, it is evident that gender-specific, age-related changes in GnRH and the gonadotropic hormones may potentially play a role in the pathogenesis of AD. ${ }^{52-55}$ Supporting a role for $\mathrm{LH}$, as opposed to estrogen, in cognitive decline after menopause, studies have demonstrated that while cognitive decline can be rescued with estrogen therapy initiated immediately after ovariectomy, hormone replacement initiated after a long interval is ineffective. ${ }^{56}$

\section{Luteinizing Hormone in Alzheimer Disease}

There is growing evidence supporting a role for gonadotropins, particularly $\mathrm{LH}$, in $\mathrm{AD}$ pathogenesis beginning with the finding of a two-fold increase in circulating gonadotropins in individuals with AD compared with age-matched controls. ${ }^{57,58}$ Since gonadotropin receptors in the brain are found within the hippocampus 59 and gonadotropins are known to cross the blood brain barrier, ${ }^{60}$ we speculate that elevated gonadotropins, namely LH, may contribute to AD pathogenesis. ${ }^{57}$ In support of this theory, we found significant elevations of $\mathrm{LH}$ in vulnerable neuronal populations in individuals with AD compared to age-matched control cases. ${ }^{61}$ Notably, such an increase in neuronal LH appears to be a very early change in disease progression serving to predict neuronal populations at risk of degeneration and death. In fact, elevations in LH parallel the ectopic expression of cell cycle and oxidative markers that represent one of the initiating pathological changes and precedes neuronal degeneration by decades. ${ }^{62,63}$

In another study using the M17 neuroblastoma cell line, LH did not alter A $\beta$ PP expression; however LH did alter A $\beta$ PP processing toward the amyloidogenic pathway as evidenced by increased secretion and insolubility of amyloid- $\beta$, decreased $\alpha$-A $\beta$ PP secretion and increased A $\beta$ PP-C99 levels. ${ }^{64}$ This same study also reported a 3.5-fold and a 1.5-fold reduction in total brain $A \beta 1-42$ and $A \beta 1-40$ concentrations, respectively, in $\mathrm{C} 57 \mathrm{BL} / 6 \mathrm{~J}$ mice treated with leuprolide acetate, a potent $\mathrm{GnRH}$ agonist shown to effectively lower serum levels of LH. ${ }^{64}$ Decreased LH levels, as a result of leuprolide acetate administration, were also shown to significantly improve hippocampally-related cognitive performance and decreased amyloid- $\beta$ deposition in aged A $\beta$ PP transgenic mice, an animal model of AD. ${ }^{65}$ These studies are the first to suggest a mechanism of LH-based neurotoxicity, namely the modulation of A $\beta P P$ processing, and also to demonstrate the potential to reverse these pathological changes by lowering LH levels with leuprolide acetate.

Offering additional evidence for the link between LH and cognition, a recent study demonstrated declines in hippocampally-associated cognitive performance as measured by the Y-maze $\operatorname{task}^{66}$ in LH- $\beta$ overexpressing mice. ${ }^{67}$ Interestingly, this study also showed that mice harboring a disrupted $\mathrm{LH}$ receptor (LHRKO) did not differ significantly in the Y-maze task between homozygous and wild-type mice, yet heterozygous mice performed significantly worse than homozygous mice. ${ }^{67}$ This intriguing result provides strong evidence suggesting that $\mathrm{LH}$-induced decreases in cognition are dependent upon the over-stimulation of $\mathrm{LH}$ receptor since the lack of an $\mathrm{LH}$ receptor in and of itself was not sufficient to evoke decreases in cognition. As previously mentioned, the LH receptor, unlike the follicle-stimulating hormone receptor, is not only expressed in the brain, ${ }^{68}$ but also known to be most highly expressed in the hippocampus, ${ }^{59}$ a region devastated by AD. It should be noted that in this study, neither LH- $\beta$ overexpressing mice nor LH receptor knockout animals showed declines in spontaneous alternation behavior in the absence of differences in overall exploratory activity. This supports the notion that the declines in Y-maze performance are hippocampal-specific rather than associated with a more general phenomenon such as overall poorer health or tumor development in these animals. This study confirms previous reports revealing that $\mathrm{LH}$ is capable of modulating cognitive behavior. ${ }^{69}$ Taken together, these findings suggest that gonadotropins such as LH may play an important role in hippocampally-related cognition and therefore, in the onset and progression of $\mathrm{AD}$.

\section{Novel AD Therapies}

In large scale clinical trials, hormone replacement therapy has not been shown to be effective in the treatment of AD, $70-72$ although at least one small study did find positive effects. ${ }^{73}$ The reason for the lack of efficacy for hormone replacement therapy is likely due to the fact that it does not restore the HPG axis to its premenopausal state since the gonadotropin-stimulating effect of activin is still increased due to the loss of inhibin after menopause. In fact, it was recently shown that hormone replacement therapy, in the form of estrogen plus progestin, administered as a therapeutic agent in a WHI Memory Study was shown to increase the risk for probable dementia in postmenopausal women age 65 years or older. ${ }^{74}$

It is only when the role of the other hormones of the HPG axis during the climacteric years and beyond is taken into account 
that the results of the WHI Memory Study can be fully and accurately explained. For instance, it is crucial when interpreting the results of this study to recognize that the hormones of the HPG axis have been in disequilibrium for decades in all women who participated in the WHI Memory Study, so if a lack of estrogen does indeed play a role in AD pathogenesis, these women have been exposed to this disease-promoting hormonal environment for years, if not decades, by the time the estrogen/progestin treatment was administered. This is evidenced by the fact that reports of probable dementia appeared within the first year of the study in both the treatment and placebo groups. Therefore, it is somewhat predictable that the administration of estrogen/progestin in these women was not only unable to restore the proper functioning of the HPG axis, but that the influx of exogenous hormones have served to exacerbate the disease process, as the consequence of increased estrogen in compromised (i.e., old) neurons may be deleterious. ${ }^{75}$

One way to revert the HPG axis to a premenopausal-like state is to lower LH using leuprolide acetate, a GnRH agonist which is known to suppress LH to undetectable levels by down regulating pituitary GnRH receptors. While the use of leuprolide in premenopausal women has resulted in memory loss and depression, ${ }^{76}$ these adverse reactions are due to the secondary abrupt loss of estrogen production, since memory deficits returned to normal after hormone replacement. ${ }^{77}$ Since women with AD are postmenopausal, having already lost their ability to produce estrogen, leuprolide acetate would be predicted to have no effect on their estrogen production. In this regard, a recently completed phase II clinical trial showed stabilization in cognitive decline and activities of daily living in a subgroup of female $\mathrm{AD}$ patients treated with high doses of leuprolide acetate coupled with an acetylcholinesterase inhibitor (http://clinicaltrials.gov/ct/show/nct00076440?orden=6). The necessity of concomitant leuprolide acetate treatment with an acetylcholinesterase inhibitor in order to observe an effect is likely reflective of the inability of leuprolide acetate to undo the neuronal damage caused by years of elevated LH. However, lessening LH-induced neurotoxicity by leuprolide acetate administration appears to be sufficient to abrogate declines in acetylcholinesterase inhibitor efficacy in this clinical trial.

It should be noted that males with $\mathrm{AD}$ were not as responsive to the effects of leuprolide acetate as were females with $A D$ in initial clinical trials. There are a number of potential confounding issues that need consideration prior to drawing any definitive conclusions. First and foremost, leuprolide acetate will deplete endogenous sex steroids, which is clearly a bigger issue for men than postmenopausal women. While testosterone supplementation was used in this initial trial, compliance and dose were clearly confounding issues. However, it has been well documented that changes associated with reproductive senescence occur at very different rates between genders and include highly gender-specific symptoms. ${ }^{78-80}$ With this in mind, the earlier chronology increasing LH in women may have pathogenic consequences that are not replicated in men whose LH only increases much later in life. ${ }^{81}$ While the results of ongoing clinical trials for the use of leuprolide acetate in the treatment of $\mathrm{AD}$ are eagerly awaited, studies investigating LH-induced pathogenesis provide a more complete paradigm of hormonal changes following reproductive senescence that contribute to $\mathrm{AD}$.

\section{References}

1. Blennow K, de Leon MJ, Zetterberg H. Alzheimer's disease. Lancet 2006;368:387-403.

2. Smith MA. Alzheimer disease. Int Rev Neurobiol 1998;42:1-54.

3. McKhann G, Drachman D, Folstein M, Katzman R, Price D, Stadlan EM. Clinical diagnosis of Alzheimer's disease: report of the NINCDS-ADRDA Work Group under the auspices of Department of Health and Human Services Task Force on Alzheimer's Disease. Neurology 1984;34:939-944.

4. Marlatt MW, Webber KM, Moreira PI, Lee HG, Casadesus G, Honda K, Zhu X, Perry G, Smith MA. Therapeutic opportunities in Alzheimer disease: one for all or all for one? Curr Med Chem 2005;12:1137-1147.

5. Bertram L, Tanzi RE. The current status of Alzheimer's disease genetics: what do we tell the patients? Pharmacol Res 2004;50:385-396.

6. Iqbal K, Zaidi T, Thompson CH, Merz PA, Wisniewski HM. Alzheimer paired helical filaments: bulk isolation, solubility, and protein composition. Acta Neuropathol (Berl) 1984;62:167-177.

7. Grundke-Iqbal I, Iqbal K, Quinlan M, Tung YC, Zaidi MS, Wisniewski HM. Microtubule-associated protein tau. A component of Alzheimer paired helical filaments. J Biol Chem 1986;261:6084-6089.

8. Lindwall G, Cole RD. Phosphorylation affects the ability of tau protein to promote microtubule assembly. J Biol Chem 1984;259:5301-5305.

9. Alonso AC, Grundke-Iqbal I, Iqbal K. Alzheimer's disease hyperphosphorylated tau sequesters normal tau into tangles of filaments and disassembles microtubules. Nat Med 1996;2:783-787.

10. Pope WB, Lambert MP, Leypold B, Seupaul R, Sletten L, Krafft G, Klein WL. Microtubule-associated protein tau is hyperphosphorylated during mitosis in the human neuroblastoma cell line SH-SY5Y. Exp Neurol 1994;126:185-194.

11. Brion JP, Octave JN, Couck AM. Distribution of the phosphorylated microtubule-associated protein tau in developing cortical neurons. Neuroscience 1994;63:895-909.

12. Brion JP, Passarier H, Nunez J, Flament-Durand J. Immunologic determinants of tau protein are present in neurofibrillary tangles of Alzheimer's disease. Arch Biol 1985;95:229-235.

13. Kanemaru K, Takio K, Miura R, Titani K, Ihara Y. Fetal-type phosphorylation of the tau in paired helical filaments. J Neurochem 1992;58:1667-1675.

14. Goedert M, Jakes R, Crowther RA, Six J, Lubke U, Vandermeeren M, Cras P, Trojanowski JQ, Lee VM. The abnormal phosphorylation of tau protein at Ser-202 in Alzheimer disease recapitulates phosphorylation during development. Proc Natl Acad Sci U S A 1993;90:5066-5070.

15. Ledesma MD, Correas I, Avila J, Diaz-Nido J. Implication of brain cdc2 and MAP2 kinases in the phosphorylation of tau protein in Alzheimer's disease. FEBS Lett 1992;308:218-224.

16. Baumann K, Mandelkow EM, Biernat J, Piwnica-Worms H, Mandelkow E. Abnormal Alzheimer-like phosphorylation of tau-protein by cyclin-dependent kinases cdk 2 and cdk5. FEBS Lett 1993;336:417-424. 
17. Arendt T, Holzer M, Grossmann A, Zedlick D, Bruckner MK. Increased expression and subcellular translocation of the mitogen activated protein kinase kinase and mitogen-activated protein kinase in Alzheimer's disease. Neuroscience 1995;68:5-18.

18. Arendt T, Rodel L, Gartner U, Holzer M. Expression of the cyclin-dependent kinase inhibitor p16 in Alzheimer's disease. Neuroreport 1996;7:3047-3049.

19. Vincent I, Rosado M, Davies P. Mitotic mechanisms in Alzheimer's disease? J Cell Biol 1996;132:413-425.

20. Nagy Z, Esiri MM, Cato AM, Smith AD. Cell cycle markers in the hippocampus in Alzheimer's disease. Acta Neuropathol (Berl) 1997;94:6-15.

21. Nagy Z, Esiri MM, Smith AD. Expression of cell division markers in the hippocampus in Alzheimer's disease and other neurodegenerative conditions. Acta Neuropathol (Berl) 1997;93:294-300.

22. Smith MA, Monnier VM, Sayre LM, Perry G. Amyloidosis, advanced glycation end products and Alzheimer disease. Neuroreport 1995;6:1595-1596.

23. Markesbery WR. Oxidative stress hypothesis in Alzheimer's disease. Free Radic Biol Med 1997;23:134-147.

24. Perry G, Smith MA. Is oxidative damage central to the pathogenesis of Alzheimer disease? Acta Neurol Belg 1998;98:175-179.

25. Curcio F, Ceriello A. Decreased cultured endothelial cell proliferation in high glucose medium is reversed by antioxidants: new insights on the pathophysiological mechanisms of diabetic vascular complications. In Vitro Cell Dev Biol 1992;28A:787-790.

26. Ferrari G, Yan CY, Greene LA. N-acetylcysteine (D- and L-stereoisomers) prevents apoptotic death of neuronal cells. J Neurosci 1995; 15:2857-2866.

27. Zhu X, Rottkamp CA, Boux H, Takeda A, Perry G, Smith MA. Activation of p38 kinase links tau phosphorylation, oxidative stress, and cell cycle-related events in Alzheimer disease. J Neuropathol Exp Neurol 2000;59:880-888.

28. McShea A, Harris PL, Webster KR, Wahl AF, Smith MA Abnormal expression of the cell cycle regulators P16 and CDK4 in Alzheimer's disease. Am J Pathol 1997;150:19331939.

29. Hirai K, Aliev G, Nunomura A, Fujioka H, Russell RL, Atwood CS, Johnson AB, Kress Y, Vinters HV, Tabaton M, Shimohama S, Cash AD, Siedlak SL, Harris PL, Jones PK, Petersen RB, Perry G, Smith MA. Mitochondrial abnormalities in Alzheimer's disease. J Neurosci 2001;21:3017-3023.

30. Zhu X, Raina AK, Perry G, Smith MA. Alzheimer's disease: the two-hit hypothesis. Lancet Neurol 2004;3:219-226.

31. Jorm AF, Korten AE, Henderson AS. The prevalence of dementia: a quantitative integration of the literature. Acta Psychiatr Scand 1987;76:465-479.

32. Breitner JC, Silverman JM, Mohs RC, Davis KL. Familial aggregation in Alzheimer's disease: comparison of risk among relatives of early-and late-onset cases, and among male and female relatives in successive generations. Neurology 1988;38:207-212.

33. Rocca WA, Hofman A, Brayne C, Breteler MM, Clarke M, Copeland JR, Dartigues JF, Engedal K, Hagnell O, Heeren TJ, Jonker C, Lindesay J, Lobo A, Mann AH, Molsa PK, Morgan K, O’Connor DW, da Silva Droux A, Sulkava R, Kay D, Amaducci L, The EURODEM-Prevalence Research Group. Frequency and distribution of Alzheimer's disease in Europe: a collaborative study of 1980-1990 prevalence findings. Ann Neurol 1991;30:381-390.

34. McGonigal G, Thomas B, McQuade C, Starr JM, MacLennan WJ, Whalley LJ. Epidemiology of Alzheimer's presenile dementia in Scotland, 1974-88. BMJ 1993;306:680-683.
35. Jorm AF, Jolley D. The incidence of dementia: a meta-analysis. Neurology 1998;51:728-733.

36. Manly JJ, Merchant CA, Jacobs DM, Small SA, Bell K, Ferin M, Mayeux R. Endogenous estrogen levels and Alzheimer's disease among postmenopausal women. Neurology 2000;54:833-837.

37. Paoletti AM, Congia S, Lello S, Tedde D, Orru M, Pistis M, Pilloni M, Zedda P, Loddo A, Melis GB. Low androgenization index in elderly women and elderly men with Alzheimer's disease. Neurology 2004;62:301-303.

38. Cunningham CJ, Sinnott M, Denihan A, Rowan M, Walsh JB, O'Moore R, Coakley D, Coen RF, Lawler BA, O'Neill DD. Endogenous sex hormone levels in postmenopausal women with Alzheimer's disease. J Clin Endocrinol Metab 2001;86:1099-1103.

39. Hogervorst E, Williams J, Combrinck M, David Smith A. Measuring serum oestradiol in women with Alzheimer's disease: the importance of the sensitivity of the assay method. Eur J Endocrinol 2003;148:67-72.

40. Barrett-Connor E, Goodman-Gruen D. Cognitive function and endogenous sex hormones in older women. J Am Geriatr Soc 1999;47:1289-1293.

41. Carlson LE, Sherwin BB, Chertkow HM. Relationships between mood and estradiol (E2) levels in Alzheimer's disease (AD) patients. J Gerontol B Psychol Sci Soc Sci 2000;55:P47-P53.

42. Yaffe K, Grady D, Pressman A, Cummings S. Serum estrogen levels, cognitive performance, and risk of cognitive decline in older community women. J Am Geriatr Soc 1998;46:816821.

43. Honjo H, Ogino Y, Naitoh K, Urabe M, Kitawaki J, Yasuda J, Yamamoto T, Ishihara S, Okada H, Yonezawa T, Hayashi K, Nambara T. In vivo effects by estrone sulfate on the central nervous system-senile dementia (Alzheimer's type). J Steroid Biochem 1989;34:521-525.

44. Rasmuson S, Nasman B, Carlstrom K, Olsson T. Increased levels of adrenocortical and gonadal hormones in mild to moderate Alzheimer's disease. Dement Geriatr Cogn Disord 2002;13:74-79.

45. Hoskin EK, Tang MX, Manly JJ, Mayeux R. Elevated sex-hormone binding globulin in elderly women with Alzheimer's disease. Neurobiol Aging 2004;25:141-147.

46. Brandi ML, Becherini L, Gennari L, Racchi M, Bianchetti A, Nacmias B, Sorbi S, Mecocci P, Senin U, Govoni S. Association of the estrogen receptor alpha gene polymorphisms with sporadic Alzheimer's disease. Biochem Biophys Res Commun 1999;265:335-338.

47. Monastero R, Cefalu AB, Camarda C, Noto D, Camarda LK, Caldarella R, Imbornone E, Averna MR, Camarda R. Association of estrogen receptor alpha gene with Alzheimer's disease: a case-control study. J Alzheimers Dis 2006;9:273278.

48. Rapp SR, Espeland MA, Shumaker SA, Henderson VW, Brunner RL, Manson JE, Gass ML, Stefanick ML, Lane DS, Hays J, Johnson KC, Coker LH, Dailey M, Bowen D; WHIMS Investigators. Effect of estrogen plus progestin on global cognitive function in postmenopausal women: the Women's Health Initiative Memory Study: a randomized controlled trial. JAMA 2003;289:2663-2672.

49. Schupf N, Kapell D, Nightingale B, Rodriguez A, Tycko B, Mayeux R. Earlier onset of Alzheimer's disease in men with Down syndrome. Neurology 1998;50:991-995.

50. Apaja PM, Harju KT, Aatsinki JT, Petaja-Repo UE, Rajaniemi HJ. Identification and structural characterization of the neuronal luteinizing hormone receptor associated with sensory systems. J Biol Chem 2004;279:1899-1906.

51. Crisanti P, Omri B, Hughes E, Meduri G, Hery C, Clauser E, Jacquemin C, Saunier B. The expression of thyrotropin receptor in the brain. Endocrinology 2001;142:812-822. 
52. Webber KM, Casadesus G, Marlatt MW, Perry G, Hamlin CR, Atwood CS, Bowen RL, Smith MA. Estrogen bows to a new master: the role of gonadotropins in Alzheimer pathogenesis. Ann N Y Acad Sci 2005;1052:201-209.

53. Smith MA, Perry G, Atwood CS, Bowen RL. Estrogen replacement and risk of Alzheimer disease. JAMA 2003;289:1100.

54. Bowen RL, Atwood CS, Perry G, Smith MA. Mechanisms involved in gender differences in Alzheimer's disease: the role of leuteinizing and follicle stimulating hormones. In: Legato MJ, ed. Principles of gender specific medicine. San Diego, CA: Elsevier Academic Press;2004. 1234-1237.

55. Casadesus G, Garrett MR, Webber KM, Hartzler AW, Atwood CS, Perry G, Bowen RL, Smith MA. The estrogen myth: potential use of gonadotropin-releasing hormone agonists for the treatment of Alzheimer's disease. Drugs R D 2006;7:187193.

56. Sherwin BB. Estrogen and memory in women: how can we reconcile the findings? Horm Behav 2005;47:371-375.

57. Bowen RL, Isley JP, Atkinson RL. An association of elevated serum gonadotropin concentrations and Alzheimer disease? J Neuroendocrinol 2000;12:351-354.

58. Short RA, Bowen RL, O'Brien PC, Graff-Radford NR. Elevated gonadotropin levels in patients with Alzheimer disease. Mayo Clin Proc 2001;76:906-909.

59. Lei ZM, Rao CV, Kornyei JL, Licht P, Hiatt ES. Novel expression of human chorionic gonadotropin/luteinizing hormone receptor gene in brain. Endocrinology 1993;132:2262-2270.

60. Lukacs H, Hiatt ES, Lei ZM, Rao CV. Peripheral and intracerebroventricular administration of human chorionic gonadotropin alters several hippocampus-associated behaviors in cycling female rats. Horm Behav 1995;29:4258.

61. Bowen RL, Smith MA, Harris PL, Kubat Z, Martins RN, Castellani RJ, Perry G, Atwood CS. Elevated luteinizing hormone expression colocalizes with neurons vulnerable to Alzheimer's disease pathology. J Neurosci Res 2002;70:514518.

62. Ogawa O, Zhu X, Lee HG, Raina A, Obrenovich ME, Bowser R, Ghanbari HA, Castellani RJ, Perry G, Smith MA. Ectopic localization of phosphorylated histone $\mathrm{H} 3$ in Alzheimer's disease: a mitotic catastrophe? Acta Neuropathol (Berl) 2003;105:524-528.

63. Nunomura A, Perry G, Aliev G, Hirai K, Takeda A, Balraj EK, Jones PK, Ghanbari H, Wataya T, Shimohama S, Chiba S, Atwood CS, Petersen RB, Smith MA. Oxidative damage is the earliest event in Alzheimer disease. J Neuropathol Exp Neurol 2001;60:759-767.

64. Bowen RL, Verdile G, Liu T, Parlow AF, Perry G, Smith MA, Martins RN, Atwood CS. Luteinizing hormone, a reproductive regulator that modulates the processing of amyloid-beta precursor protein and amyloid-beta deposition. J Biol Chem 2004;279:20539-20545.

65. Casadesus G, Webber KM, Atwood CS, Pappolla MA, Perry G, Bowen RL, Smith MA. Luteinizing hormone modulates cognition and amyloid-beta deposition in Alzheimer APP transgenic mice. Biochim Biophys Acta 2006;1762:447-452.

66. Lalonde R. The neurobiological basis of spontaneous alternation. Neurosci Biobehav Rev 2002;26:91-104.

67. Casadesus G, Milliken EL, Webber KM, Bowen RL, Lei Z, Rao CV, Perry G, Keri RA, Smith MA. Increases in luteinizing hormone are associated with declines in cognitive performance. Mol Cell Endocrinol 2007;269:107-111.
68. Bukovsky A, Indrapichate K, Fujiwara H, Cekanova M, Ayala ME, Dominguez R, Caudle MR, Wimalsena J, Elder RF, Copas P, Foster JS, Fernando RI, Henley DC, Upadhyaya NB. Multiple luteinizing hormone receptor (LHR) protein variants, interspecies reactivity of anti-LHR mAb clone 3B5, subcellular localization of LHR in human placenta, pelvic floor and brain, and possible role for LHR in the development of abnormal pregnancy, pelvic floor disorders and Alzheimer's disease. Reprod Biol Endocrinol 2003;1:46.

69. Chakravarti S, Collins WP, Forecast JD, Newton JR, Oram DH, Studd JW. Hormonal profiles after the menopause. Br Med J 1976;2:784-787.

70. Henderson VW, Paganini-Hill A, Miller BL, Elble RJ, Reyes PF, Shoupe D, McCleary CA, Klein RA, Hake AM, Farlow MR. Estrogen for Alzheimer's disease in women: randomized, double-blind, placebo-controlled trial. Neurology 2000;54:295-301.

71. Mulnard RA. Estrogen as a treatment for alzheimer disease. JAMA 2000;284:307-308.

72. Mulnard RA, Cotman CW, Kawas C, van Dyck CH, Sano M, Doody R, Koss E, Pfeiffer E, Jin S, Gamst A, Grundman M, Thomas R, Thal LJ. Estrogen replacement therapy for treatment of mild to moderate Alzheimer disease: a randomized controlled trial. Alzheimer's Disease Cooperative Study. JAMA 2000;283:1007-1015.

73. Asthana S, Baker LD, Craft S, Stanczyk FZ, Veith RC, Raskind MA, Plymate SR. High-dose estradiol improves cognition for women with AD: results of a randomized study. Neurology 2001;57:605-612.

74. Shumaker SA, Legault C, Rapp SR, Thal L, Wallace RB, Ockene JK, Hendrix SL, Jones BN 3rd, Assaf AR, Jackson RD, Kotchen JM, Wassertheil-Smoller S, Wactawski-Wende $\mathrm{J}$; WHIMS Investigators. Estrogen plus progestin and the incidence of dementia and mild cognitive impairment in postmenopausal women: the Women's Health Initiative Memory Study: a randomized controlled trial. JAMA 2003;289:2651-2662.

75. Chen S, Nilsen J, Brinton RD. Dose and temporal pattern of estrogen exposure determines neuroprotective outcome in hippocampal neurons: therapeutic implications. Endocrinology 2006; 147:5303-5313.

76. Varney NR, Syrop C, Kubu CS, Struchen M, Hahn S, Franzen K. Neuropsychologic dysfunction in women following leuprolide acetate induction of hypoestrogenism. J Assist Reprod Genet 1993;10:53-57.

77. Sherwin BB, Tulandi T. "Add-back" estrogen reverses cognitive deficits induced by a gonadotropin-releasing hormone agonist in women with leiomyomata uteri. J Clin Endocrinol Metab 1996;81:2545-2549.

78. Handelsman DJ. Male reproductive ageing: human fertility, androgens and hormone dependent disease. Novartis Found Symp 2002;242:66-77.

79. Pommerville PJ, Zakus P. Andropause: knowledge and awareness among primary care physicians in Victoria, BC, Canada. Aging Male 2006;9:215-220.

80. Jannini EA, Carosa E, Rossi S, Di Sante S, Sebastiani G, Lenzi A. Ageing and male sexuality. Minerva Ginecol 2007;59:3541.

81. Hogervorst E, Bandelow S, Moffat SD. Increasing testosterone levels and effects on cognitive functions in elderly men and women: a review. Curr Drug Targets CNS Neurol Disord 2005;4:531-540. 
Author Affiliations

Kate M. Webber, PhD

Department of Pathology

Case Western Reserve University

Cleveland, Ohio

George Perry, PhD

Department of Pathology

Case Western Reserve University

Cleveland, Ohio and

College of Sciences

University of Texas at San Antonio

San Antonio, Texas

Mark A. Smith, PhD

Department of Pathology

Case Western Reserve University

Cleveland, Ohio

Gemma Casadesus, PhD

Department of Neurosciences

Case Western Reserve University

Cleveland, Ohio 